\title{
Emerging temporality: past tense and temporal/ aspectual markers in Spanish-speaking children's intra-conversational narratives
}

\section{Citation}

UCCELLI, PAOLA. 2009. "Emerging temporality: past tense and temporal/aspectual markers in Spanish-speaking children s intra-conversational narratives." Journal of Child Language 36 (05) (November 19): 929. doi:10.1017/S0305000908009288. http://dx.doi.org/10.1017/ S0305000908009288.

\section{Published Version}

doi:10.1017/S0305000908009288

\section{Permanent link}

http://nrs.harvard.edu/urn-3:HUL.InstRepos:11380187

\section{Terms of Use}

This article was downloaded from Harvard University's DASH repository, and is made available under the terms and conditions applicable to Other Posted Material, as set forth at http:// nrs.harvard.edu/urn-3:HUL.InstRepos:dash.current.terms-of-use\#LAA

\section{Share Your Story}

The Harvard community has made this article openly available.

Please share how this access benefits you. Submit a story.

Accessibility 
7. Child Lang. 36 (2009), 929-966. (c) 2009 Cambridge University Press doi:I0.1017/So305000908009288 Printed in the United Kingdom

\title{
Emerging temporality: past tense and temporal/ aspectual markers in Spanish-speaking children's intra-conversational narratives*
}

\author{
PAOLA UCCELLI \\ Harvard Graduate School of Education
}

(Received 3 Fanuary 2006. Revised 8 October 2007. First published online I9 February 2009)

\section{ABSTRACT}

This study describes how young Spanish-speaking children become gradually more adept at encoding temporality using grammar and discourse skills in intra-conversational narratives. The research involved parallel case studies of two Spanish-speaking children followed longitudinally from ages two to three. Type/token frequencies of verb tense, temporal/aspectual markers and narrative components were analyzed to explore interrelationships among grammatical and discourse skills. Children progressed from scattered unsystematic means of encoding temporality to mastering a basic linguistic system that included devices to mark LOCATION OF EVENTS, TEMPORAL RELATIONS and ASPECTUAL MEANINGS. The consolidation of perfective past tense to express narrative events marked a crucial developmental point which preceded an explosion of additional verb tenses and temporal markers. The value of spontaneous language data, and the need to study grammar and discourse simultaneously to construct a comprehensive developmental picture are highlighted. Results are discussed in relation to theoretical proposals on the development of temporality.

\section{INTRODUCTION}

The aims of this study are twofold. The first is to document how the use of past tense verbs changes over time in Spanish-speaking children's intra-conversational narratives from two to three years of age. The second is to explore children's use of past tense verbs in relation to their use of

[*] I am grateful to the three members of my dissertation committee: my advisor Catherine Snow, and my readers Lowry Hemphill and Martha Shiro. Special thanks are due to Susana López Ornat and her research team for donating María's corpus to the CHILDES database, and to Gigliana Melzi for her valuable help in the reliability process. Isabella and María have my endless gratitude. Address for correspondence: Harvard Graduate School of Education, 422 Larsen Hall, I 4 Appian Way, Cambridge, MA o2 I38. e-mail: paola_uccelli@gse.harvard.edu 
temporal/aspectual markers in co-constructed narrative discourse at this early age. Interrelationships among grammatical and discourse skills are described for two monolingual Spanish speakers throughout their third year of life as they become gradually more adept at encoding temporality.

Narratives emerge in the context of heavily scaffolded parent-child conversations as early as two years of age. Starting at about age two, the major developmental tasks within language development include perfecting grammatical skills and acquiring discourse skills essential to producing longer stretches of talk such as narratives (Ninio \& Snow, I996). A particular challenge characteristic of narrative development is TEMPORAL DISPLACEMENT, i.e. the ability to communicate about events that lie outside the immediate context of the conversation (Ninio \& Snow, I996; Sachs, I983). Children's first conversations center on persons, objects or events that are present in their environment. In narratives about past or fictional events, children have to move from the 'here-and-now' to the 'there-andthen', and thus cannot rely as much on contextual support (Sachs, i 983 ). This discourse genre requires, in Gerhardt's ( 1988 : 205) words, 'the capacity to use language as its own context'. Indeed, contextual support needs to be replaced by the linguistic skills required to express, among other relations, the temporal connections necessary to construct a narrative. Temporality is a crucial dimension of narratives as the temporal sequence of events is what moves the plot forward (Labov \& Waletzky, i 967).

Temporality is defined here as 'the expression of the location of events on the timeline, temporal relations between events and temporal constituency of events [i.e. aspectual information]' (Berman \& Slobin, I994: I9). Speakers signal temporal information through language in multiple ways: via grammatical morphemes such as tense/aspect marking on verbs; via lexical items such as temporal/aspectual adverbs, connectives and expressions (later, then); and via discourse strategies, such as the sequential disposition of events in a narrative. Even though most languages make use of grammatical, lexical and discourse devices for expressing temporality, the mappings between temporal notions and linguistic forms vary from language to language, making the development of temporality language-specific (Berman \& Slobin, I994; Hickmann, 2003). Spanish is an interesting language for the study of temporal expression because its complex verbal paradigm richly encodes temporal and aspectual relations.

The Spanish verbal system offers a particularly researchable developmental challenge in that control of the full paradigm requires, in addition to attention to number and person, control over three tenses (past, present and future), at least four aspects (perfective, imperfective, perfect and progressive) and three moods (indicative, subjunctive and imperative). Spanish has a synthetic morphology; there are forty-plus distinctively marked forms of each verb stem, as well as additional twenty-plus forms created with auxiliary verbs that 
themselves display the full paradigm differentiation. Spanish marks a past/ non-past distinction. Past events are marked whereas present tense forms can express both present and future events. The three most frequently used forms traditionally described as conveying temporal distances prior to the moment of speech are: present perfect (recent past: he cantado), preterite (distant past: canté) and pluperfect (past in the past: había cantado). Supplementary verb inflections mark additional temporal relations and aspectual contours of past actions: imperfect (cantaba), progressive with an imperfect auxiliary (estaba cantando), progressive with a perfective auxiliary (estuve cantando) and prospective imperfect (iba a cantar). ${ }^{1}$

Grammarians have traditionally described the Spanish PRETERITE as referring to completed past situations, and the PRESENT PERFECT as establishing a relation of simultaneity with the present, be it because the referred past action has not yet ended, or because its consequences are still visible or relevant to the present situation (Bello, I984). This distinction, however, is not equally realized in all Spanish varieties. Contrastive studies of adult Peninsular vs. American Spanish have reported a preferred use of preterite forms in American Spanish as opposed to a more prominent use of present perfect in Spain $^{2}$ (Moreno de Alba, I993). The use of the present perfect has adopted an increasing perfective meaning in Spain, so that it is more often used to refer to completed past events. In contrast, in nearly all American Spanish varieties most past events are reported via the preterite because the present perfect has adopted an increasing present meaning that results in its restricted use for CONTINUATIVE actions; those that continue to be relevant in the present (De Jonge, I995).

In narrative discourse, most Peninsular and American Spanish varieties use perfective forms (present perfect or preterite) to report foregrounded events that advance the plot. Imperfective forms usually convey continuous, iterative or habitual actions. Even though imperfective forms might appear

[I] The inclusion of the PROSPECtive imperfect as part of the Spanish verbal paradigm is an issue of debate among Spanish grammarians. Following Cartagena (r 999), I include this form as an independent tense/aspect inflection given its distinctive temporal meaning. Cartagena (1999: 2967) describes this form as indicating 'posterioridad respecto de las [formas] primarias ... hacía (o hice), es decir relaciones de posterioridad medidas dentro del ámbito ... del pasado'. The additional form of the anterior preterite (hube cantado) has fallen into disuse and constitutes nowadays an archaic form even in written discourse. The conditional forms are additional forms to talk about the past, but they refer to the hypothetical past (hubiese/ra cantado, habria cantado). They are not mentioned because they go beyond the aspectual distinction and display a difference in verb mood. These complex forms are acquired later and were not present in these datasets.

[2] Even though both Spain and Hispanic America are vast geographical areas that encompass a large number of language varieties, some general tendencies have been associated as predominant in most Peninsular Spanish varieties as compared to most American Spanish varieties. These tendencies are not shared by all varieties, though. Within Hispanic America, for instance, a more prominent use of the present perfect is characteristic of Andean Spanish varieties (De Jonge, I995). 
throughout a narrative, this tense is most frequently used for setting or background information (Silva-Corvalán, 2004). Spanish also encodes temporal information in a variety of lexical items (adverbs, connectives).

\section{Verbs}

Despite the large body of research on verb development in Spanish, the expression of temporality, which requires a broader analytical lens, has been minimally explored. One crucial contribution is Berman \& Slobin's ( 1994) cross-linguistic study of children's narratives starting at age three. In their analysis of the Spanish corpora, Sebastián \& Slobin (1994: 242) report that:

Almost every combination [of tense/aspect forms] is attested in the 3-year-old sample from Spain, and comparison with the Chilean and

Argentinean data convinces us that we did not chance upon a particularly precocious sample in Madrid.

These researchers describe Spanish-speaking children as precocious in their use of tense/aspect inflections and suggest that the complexity of the Spanish system, far from impeding its acquisition, seems to facilitate it.

This abundance of forms at such an early age leads to the following question: How do young Spanish-speaking children's linguistic skills progress so that by three years of age they are able to use almost the full array of tense/aspect forms in narration?

Spanish-speaking children as young as two years of age start using verb inflections to express temporal contrasts (Fernández, I994; Gathercole, Sebastián \& Soto, I 999). A piecemeal - as opposed to 'across-the-board'acquisition has been documented as 'the Spanish-speaking child moves step by step towards productivity by learning forms verb by verb' (Gathercole et al., I999: 30). Verb semantics has also been invoked as an influential variable contributing to an early yet selective acquisition of past tense inflections (Jackson-Maldonado \& Maldonado, 200 I).

Despite the early acquisition and diversity of forms documented, several studies have reported minimal presence of past tense forms before age three (González, I980; Peronard, I987; Morales, I989; Johnson, I996). According to González, ( I980: 8), his participants aged 2;6 produced the imperfect, imperfect progressive and pluperfect 'too infrequently to warrant discussion'. Morales ( I989), in her cross-sectional study of Puerto Rican children aged two to six, concluded that narrative via past tense verbs does not emerge until after age three. More radically, Johnson ( I 996) reported minimal productivity of verb tenses up to age four.

In sum, on the one hand studies on acquisition report an early emergence of past forms offering analyses that take into account the communicative function, the interactional context or verb semantics early in development 
(Fernández, I994; Gathercole et al., I999; Jackson-Maldonado \& Maldonado, 200I, respectively). On the other hand, studies that focus on the subsequent use of past tense from ages two to three highlight the scarcity or even absence of these inflections. These latter studies are based on cross-sectional samples, and do not take into consideration the larger context. In particular, discourse genre and function are generally overlooked. In contrast, Sebastián \& Slobin ( I 994) report the abundance of forms by age three in a specific discourse: narrative. The present study seeks to clarify these contradictory results by closely following the use of past tense verbs in intra-conversational narratives from two to three years of age.

\section{Temporal/aspectual markers}

Most research on temporal/aspectual markers before age three in Spanish offers lists of isolated forms without considering the discourse context or functions. One exception is Sebastián, Slobin and colleagues, who found that three-year-old narrators produced aspectual markers ${ }^{3} y^{a}$ 'already' and otra vez 'again' to express result and recurrence, respectively; general sequencers entonces 'then', luego 'after'; a few anaphoric expressions; and the subordinating conjunction cuando 'when' to mark immediate anteriority or simultaneity (e.g. Sebastián \& Slobin, I 994). Other studies report the early appearance of ya, ahora, mañana; at least one sequencer entonces, después or luego; the conjunction cuando; some deictic adverbs (e.g. ayer, hoy); and a few phrases expressing reference time (e.g. en la mañana, hace tiempo) (González, I980; Hernández Pina, I984) but without offering any further analysis on discourse context.

\section{Verbs and temporal markers}

To my knowledge, only one study-Eisenberg (1985)-has described concurrent grammatical and discourse development of temporality for children younger than three years of age in Spanish. Eisenberg contributed a valuable description of the emergence of temporally displaced talk in a longitudinal analysis of two Spanish-speaking children from approximately two to three years of age. She summarized the developmental changes into three phases. In the first phase, the fact that Spanish-speaking children and adults were talking about the past was established by the adults' use of tense forms, while children's contributions were simple nominals or infinitives. Children produced a few verbs in the context of simple adult-initiated routines. In the second phase, children became less dependent on adults'

[3] Spanish aspectual markers identified by Berman \& Slobin (r984) included adverbs and expressions used to mark aspectual meanings, such as recurrence or completion. 
scaffolding with most utterances containing past tense verbs. Finally, in the third phase, children spontaneously initiated past talk, including adverbs and conjunctions. Adverbs and connectives were scarcely used before age three, with the latter being used initially as EMPTY links in descriptions of past events, and only later used 'appropriately' (Eisenberg, I985: 192).

Eisenberg documented a considerable advance in discourse autonomy and an increasing frequency of grammatical forms. However, she did not explore specific verb tenses, distinct temporal markers or discourse functions and how they relate to each other. Eisenberg's study raised a still unanswered question: How do changes in discourse skills relate to grammatical development over time from ages two to three? This study intends to take Eisenberg's analysis one step further to investigate interrelationships among lexico-grammatical and discourse skills.

\section{Theoretical proposals}

In the study of the emergence of temporality, whether young children are cognitively and linguistically able to refer to the past has been a controversy for a long time. Piaget concluded that young children were cognitively too immature to handle the temporal concept of pastness before age six (Piaget, i 969). However, Halliday ( 1975) reported that his son Nigel at i;6 would spontaneously narrate past happenings to a familiar adult via rudimentary linguistic means. While research on productivity of verb tenses has reported an early acquisition of the present vs. past tense contrast, whether these tense inflections refer to a deictic past or not has remained controversial. Shirai \& Miyata (2006) have clarified this discussion by documenting a distinction between initial contrastive use of past tense and use of deictic past. In their longitudinal analysis of Japanese children between ages I ; 2 and $2 ; 5$, these authors found that the contrastive use of past tense preceded the use of deictic past.

The development of temporality has been further illuminated by Katherine Nelson's and Richard Weist's contributions. Based on her research on Emily's narratives and her script data, Nelson ( 1989; г996) raises three developmental claims about the mutual influence of event knowledge and language use. First, she argues that in the acquisition of tense inflections 'language makes salient a type of relation that was not previously apparent in the child's nonlinguistic conceptual representations'. She points out that before acquiring the tense system, children may only distinguish between now and not-now (Gerhardt, I989) or might express exclusively actions related to present circumstances. Via the use of tense inflections consistently associated with distinct time points, children learn the conceptual distinction of past, present and future (in languages that make such distinctions). Her second claim points to the inverse effect of cognitive representation 
facilitating language acquisition. Nelson argues that 'nonlinguistic experientially derived' event representations - including notions of sequence, duration and frequency - facilitate the acquisition of linguistic forms that express these relations. In Nelson's words '[i]n this case, language makes explicit knowledge that was previously implicit' (r996: 289-90). Finally, she points out that language makes accessible abstract concepts that cannot be acquired through experience, in particular conventional markings of time, such as hours, days, months, etc. Conventional time markers require explicit instruction and are typically learned at school.

Weist \& Buczowska ( I 987) suggest a four-phase development of temporal reference, based on Smith's ( I980) proposal. Weist and Buczowska's model places the first phase at the emergence of language production, which they describe as restricted to the 'here-and-now' of SPEECH TIME (ST). In the second phase, children begin to mark events as past, present or future in relation to ST via tense inflections, in other words, EVENT TIME (ET) becomes independent from ST, e.g. Tower fell down. In the third phase, between about $2 ; 6$ and $3 ; 0$, temporal/aspectual markers emerge, and consequently children start conveying REFERENCE TIME (RT). At this phase, however, RT can only be concurrent with ET, e.g. When I was at school [RT], I cried [ET]. In the fourth phase, not until 3;6 or 4;o, ST, ET and RT can be related freely, establishing simultaneous, anterior or posterior relations among the three, e.g. I cried [ET] before I went to school [RT]. This account comprises not only a gradual inclusion of more linguistic time points, but an increasing flexibility and complexity in the relationships potentially established among them.

Despite the complementary nature of Nelson's and Weist's proposals, there are some points of controversy. In line with Weist's model, previous studies on English have reported that temporal markers are not acquired until after tense contrasts are productively used (Bloom, Lifter \& Hafitz, I980). Nevertheless, Nelson's ( I989) analysis showed that Emily's crib monologues displayed temporal adverbials AT THE SAME TIME as the tense system was being organized. In addition, Nelson foregrounds the role of discourse, highlighting Weist's exclusive focus on sentence-level connections (Nelson, I989: 301). Nelson argues that by looking at entire narratives, instead of isolated sentences, it is possible to find not only sequential relations among events, but also ST-ET-RT relations much earlier than Weist's model indicates. In fact, she argues that children's struggles to order events drive them to master tense usage and temporal markers (Nelson, i 989: 304-305).

Whether Spanish-speaking children produce temporal markers in synchrony with or only after the productive use of the tense system is still an unanswered question. Whether Spanish-speaking children follow Weist's model or are able to produce more precocious combinations of time 
perspectives earlier in discourse also remains to be explored. This study examines the synchronous and asynchronous relationships among different temporal skills at the grammatical and discourse levels to relate the findings to the theoretical claims just reviewed.

\section{METHODS}

The design involved comparative case studies of two young Spanishspeaking children followed longitudinally during a one-year span. Children were recorded in spontaneous parent-child conversations from two to three years of age. Both children were monolingual speakers of Spanish, were the first-born and only child in their families, and came from middle-class households.

\section{Maria}

María's longitudinal dataset was published by López Ornat, Fernández, Gallo \& Mariscal (I994) and is available in CHAT format through the CHILDES Database (MacWhinney, 2000). María is a girl from Madrid, Spain. From age one to age four, María was videotaped biweekly in sessions of approximately thirty minutes. Sessions took place at home during spontaneous interactions with familiar adults. For this study, the twelve published sessions from age 2; 0 to 3; I were selected for analysis.

\section{Isabella}

Isabella was audio-recorded every fifteen days in sessions of about thirty minutes to an hour. Sessions took place at home during spontaneous interactions with her parents, who are from Latin America (father is from San Juan, Puerto Rico and mother is from Lima, Perú). ${ }^{4}$ Isabella's dataset was fully transcribed following CHAT conventions. It comprises eleven time points from age $2 ; 2$ to age $3 ; 3$.

\section{Defining a narrative: data selection}

Labov \& Waletzky ( I967: 28) defined a minimal narrative as a sequence of two restricted [independent] clauses which are temporally ordered. Starting with Peterson \& McCabe (I983), this characterization has guided most linguistic approaches to narrative development. As Bamberg (1997) has pointed out, this definition implies a minimum requirement of two events

[4] Despite growing up in the US, Isabella lived in a Spanish-speaking micro-world, with parents who spoke only Spanish at home, a monolingual Spanish-speaking babysitter and Spanish-speaking friends. 
sequentially ordered and it is ubiquitously assumed that it requires predicates marked by tensed verbs. After examining María's and Isabella's language exchanges, the need to stretch the boundaries of this definition became evident. In child language there is a long history of including protoforms in one's analysis, e.g. speech acts (Bates, Camaioni \& Volterra, I 975), or grammatical markers (Brown, I973). Including predecessors of later more advanced forms is needed to understand the origins of narratives. For this study intra-conversational narratives ${ }^{5}$ were defined as consisting of at least two contiguous and topically related child utterances that referred to any two components of a past or fictional happening (event, setting, evaluation and/or speech). This expanded definition includes proto-narratives - i.e. narratives that refer to a temporally displaced happening even without containing a clear tensed verb - and encompasses both personal and fictional renditions of events.

Narrative segments were identified in transcripts using the GEM program from CLAN (MacWhinney, 2000). Shifts from and to 'here-andnow' talk were especially helpful in identifying narrative boundaries, as were explicit elicitation attempts by parents. Narratives were coded for lexico-grammatical and discourse measures. The measures reported here comprise a subset of the original coding system (for further details see Uccelli, 2003).

\section{Discourse measures}

At the discourse level, narratives were divided into narrative clauses, which were coded for narrative components following highpoint analysis (Peterson \& McCabe's (I983) adaptation of the Labovian narrative analysis):

EVENT CLAUSES: report actions that constitute the backbone of the story and serve to advance the plot. ${ }^{6}$

SETTING CLAUSES: offer referential information about space, time, characters and general background information. TEMPORAL SETTING clauses are of particular interest in this study.

EVALUATIVE CLAUSES: provide the narrator's stance towards the narrated events via qualifications, explanations, expressions of emotions and emphatic assertions, among others.

[5] Throughout this article, the term NARRATives will be used to refer to the language produced by children in the context of intra-conversational narratives co-constructed with familiar adults.

[6] In this study, NarRative Event Clauses included all possible event clauses identified by Peterson \& McCabe (I983) : ( I) Complicating actions; (2) high point action; and (3) RESOLUTIONs. For these young narrators, distinguishing among these three subtypes was not always possible or relevant. 
TABLE I. Maria's data: raw frequencies of general narrative measures

\begin{tabular}{|c|c|c|c|c|c|c|c|}
\hline Age & $\begin{array}{c}\text { Total } \\
\text { narratives }\end{array}$ & $\begin{array}{c}\text { Total } \\
\text { utterances }\end{array}$ & $\begin{array}{l}\text { Total } \\
\text { clauses }\end{array}$ & $\begin{array}{l}\text { Narrative } \\
\text { clauses }\end{array}$ & $\begin{array}{c}\text { Non- } \\
\text { narrative } \\
\text { clauses }\end{array}$ & $\begin{array}{c}\text { Narrative } \\
\text { clauses/total } \\
\text { narratives }\end{array}$ & $\begin{array}{c}\text { Range of } \\
\text { narrative } \\
\text { clauses per } \\
\text { narrative }\end{array}$ \\
\hline $2 ; 0$ & 4 & 24 & 26 & I 7 & 9 & $4 \cdot 3$ & $2-I 4$ \\
\hline $2 ; \mathrm{I}$ & I 2 & I I I & I 20 & 70 & 50 & $5 \cdot 8$ & $2-19$ \\
\hline $2 ; 2$ & 7 & 82 & 90 & 48 & 42 & $6 \cdot 7$ & $2-I 3$ \\
\hline $2 ; 3$ & 9 & 59 & 80 & 53 & 27 & $5 \cdot 9$ & $3-10$ \\
\hline $2 ; 4$ & 4 & 32 & $4 \mathrm{I}$ & $2 I$ & I9 & $5 \cdot 3$ & $4-8$ \\
\hline $2 ; 5$ & I I & $7 \mathrm{I}$ & 98 & 72 & 26 & $6 \cdot 6$ & $2-18$ \\
\hline $2 ; 6-2 ; 8 *$ & 5 & $4 \mathrm{I}$ & 56 & 45 & IO & 9 & $2-I 2$ \\
\hline $2 ; 9$ & 7 & I I 9 & 192 & I 32 & 59 & I $8 \cdot 9$ & $8-33$ \\
\hline 2 ; I I & 7 & 84 & I 2 I & 85 & 36 & I $2 \cdot 2$ & $3^{-25}$ \\
\hline $3 ; \mathrm{I}$ & I I & 98 & 105 & 70 & 35 & $6 \cdot 4$ & $3^{-19}$ \\
\hline TOTAL & 77 & 721 & 93 I & 617 & 3 I 4 & $8 \cdot 0 \mathrm{I}$ & $2-33$ \\
\hline
\end{tabular}

* Three sessions were combined due to the low incidence of narratives in each of them. From now on this time period which combines data from ages $2 ; 6,2 ; 7$ and $2 ; 8$ will be referred to using the older age : $2 ; 8$.

Additional narrative components include SPEECH CLAUSES which express characters' reported or indirect speech, and oPENINGS and CLOSINGS which mark the beginning and end of narratives (see Appendix). ${ }^{7}$ Mean frequencies of narrative components were generated.

Inter-rater reliability for narrative components was estimated using Cohen's kappa statistics (Bakeman \& Gottman, I 997). A native Spanishspeaking researcher independently coded fifteen percent of the narratives in each corpus. Cohen's kappa statistic was 0.94 for narrative components.

\section{Lexico-grammatical measures}

FREQUENCY OF VERBS (TYPES AND TOKENS): verbs were coded for verb stem, person and tense.

FREQUENCY OF TEMPORAL/ASPECTUAL MARKERS (TYPES AND TOKENS): adverbs, connectives and other temporal expressions were identified.

\section{RESULTS}

\section{Discourse measures}

Narrative length. Tables I and 2 display, for each time point, the total number of narratives produced, and the total frequencies of basic narrative

[7] Speech was coded as an independent component, instead of being included under evaluation, because in these data quoted speech served not only to evaluate, but often served also to advance the plot. 
TA B LE 2. Isabella's data: raw frequencies of general narrative measures

\begin{tabular}{|c|c|c|c|c|c|c|c|}
\hline Age & $\begin{array}{c}\text { Total } \\
\text { narratives }\end{array}$ & $\begin{array}{c}\text { Total } \\
\text { utterances }\end{array}$ & $\begin{array}{l}\text { Total } \\
\text { clauses }\end{array}$ & $\begin{array}{c}\text { Narrative } \\
\text { clauses }\end{array}$ & $\begin{array}{c}\text { Non- } \\
\text { narrative } \\
\text { clauses }\end{array}$ & $\begin{array}{c}\text { Narrative } \\
\text { clauses/total } \\
\text { narratives }\end{array}$ & $\begin{array}{c}\text { Range of } \\
\text { narrative } \\
\text { clauses per } \\
\text { narrative }\end{array}$ \\
\hline $2 ; 2$ & 9 & Io6 & I 20 & 94 & 26 & I 0.4 & $3^{-20}$ \\
\hline $2 ; 3$ & I 3 & 201 & 208 & 125 & 83 & $9 \cdot 6$ & $6-3 I$ \\
\hline $2 ; 4$ & 5 & 77 & 83 & 60 & 23 & I 2 & $3^{-I 9}$ \\
\hline $2 ; 5$ & IO & I 76 & I 90 & I 34 & $5^{6}$ & I 3.4 & $2-27$ \\
\hline $2 ; 7$ & 7 & 102 & I I 4 & 79 & 35 & I I 3 & $6-\mathrm{I} 3$ \\
\hline $2 ; 8$ & 7 & 65 & 75 & 53 & 22 & $7 \cdot 6$ & $3^{-I} 4$ \\
\hline $2 ; 9$ & I 3 & I 35 & I 55 & I 24 & 30 & $9 \cdot 5$ & $2-28$ \\
\hline $2 ; 10$ & I 4 & 220 & 287 & 201 & 86 & I 4.4 & $4^{-25}$ \\
\hline 2 ; I I & I 5 & I 89 & 226 & I 67 & 59 & $I I \cdot I$ & $2-22$ \\
\hline $3 ; \mathrm{I}$ & 7 & 92 & I 3 I & 99 & 32 & I $4 \cdot \mathrm{I}$ & $5-42$ \\
\hline $3 ; 3$ & I 5 & I 9 I & 269 & 2 I I & $5^{8}$ & I $4{ }^{\circ} \mathrm{I}$ & $3-35$ \\
\hline TOTAL & I I 5 & I 554 & I 858 & I 347 & 510 & I I $\cdot 7$ & $2-42$ \\
\hline
\end{tabular}

units. Overall narrative length increased on average for both girls over time, in accordance with the positive association between narrative length and age reported in the literature on children's personal narratives (Peterson \& McCabe, r 983). However, it is worth highlighting that narratives exhibited a variety of lengths throughout most time periods with short and long narratives present at both ends of the data collection sessions. It is also noticeable that Isabella tended to produce somewhat longer narratives.

Maria's progress appears somewhat distorted towards the end of the year by the fact that she was disinclined to talk at $3 ; \mathrm{I}$, after she had been engaged in extended autonomous narrative at 2;9 and 2; I I (see María's narrative under 'Diversity and integration of temporal/aspectual markers'). In fact, María's last session offers an unusually poor performance overall, probably as the result of the family being on vacation. A quote from her mother confirms María's reluctance to talk during this session:

MOTHER: Hoy no quieres hablar nada, ¿eh?

'Today you don't want to talk at all, do you?'

Thus, I will not interpret this last performance as a developmental regression, but just as the result of external circumstances affecting María's motivation to narrate.

Narrative components. Figures I and 2 show the frequency of event clauses as compared to setting and evaluation clauses. For María, narratives initially consisted mostly of elicited setting information with a range of one to two events per narrative and minimal evaluation. At 2;4, the frequency of event clauses increased considerably, while setting clauses became less frequent. In the last three months of her third year, the frequencies of event, setting 


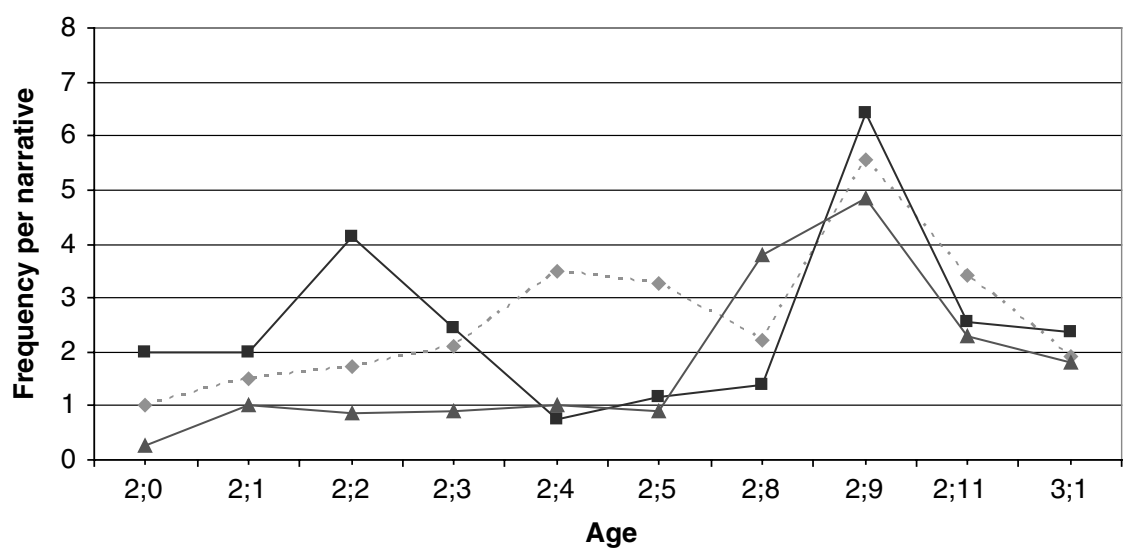

$\ldots$ - Event clauses $\longrightarrow$ Setting clauses $\longrightarrow \longleftarrow$ Evaluation clauses

Fig. I. MARIA: Frequency of major narrative components.

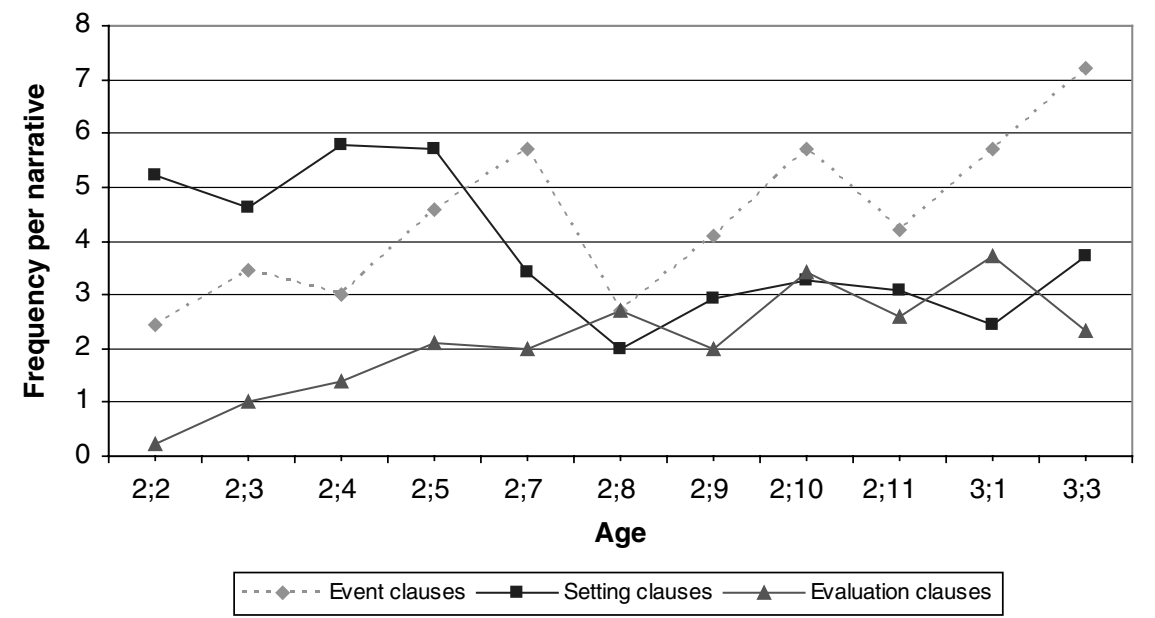

Fig. 2. ISABELLA: Frequency of major narrative components.

and evaluation clauses per narrative became more balanced, with events constituting a third of all main narrative components (see Figure I).

For Isabella, narratives also consisted initially mostly of elicited setting information, but from the beginning Isabella's narratives displayed a higher number of event clauses than María's. Over time, setting and evaluation became more balanced, but event clauses continued to dominate Isabella's 
TABLE 3. Frequency of reported events (proto-narratives are excluded)

\begin{tabular}{|c|c|c|c|}
\hline \multicolumn{4}{|c|}{ María } \\
\hline Age & $\begin{array}{c}\text { Total } \\
\text { narratives }\end{array}$ & $\begin{array}{l}\text { Reported } \\
\text { events }\end{array}$ & $\begin{array}{c}\text { Reported events/ } \\
\text { Narratives }\end{array}$ \\
\hline $2 ; 0$ & I & 2 & $2 \cdot 0$ \\
\hline $2 ; \mathrm{I}$ & 8 & I 6 & $2 \cdot 0$ \\
\hline $2 ; 2$ & 3 & 7 & $2 \cdot 3$ \\
\hline $2 ; 3$ & 5 & I 2 & $2 \cdot 4$ \\
\hline $2 ; 4$ & 4 & I I & $2 \cdot 8$ \\
\hline $2 ; 5$ & 5 & 24 & $4 \cdot 8$ \\
\hline $2 ; 8$ & 3 & 7 & $2 \cdot 3$ \\
\hline $2 ; 9$ & 6 & 25 & $4 \cdot 2$ \\
\hline 2 ; I I & 5 & I 7 & $3 \cdot 4$ \\
\hline $3 ; \mathrm{I}$ & 4 & I I & $2 \cdot 8$ \\
\hline \multicolumn{4}{|c|}{ Isabella } \\
\hline Age & $\begin{array}{c}\text { Total } \\
\text { narratives }\end{array}$ & $\begin{array}{l}\text { Reported } \\
\text { events }\end{array}$ & $\begin{array}{c}\text { Reported events/ } \\
\text { Narratives }\end{array}$ \\
\hline $2 ; 2$ & 5 & I 4 & $2 \cdot 8$ \\
\hline $2 ; 3$ & 9 & 30 & $3 \cdot 3$ \\
\hline $2 ; 4$ & 4 & IO & $2 \cdot 5$ \\
\hline $2 ; 5$ & 6 & 23 & $3 \cdot 8$ \\
\hline $2 ; 7$ & 7 & 25 & $3 \cdot 6$ \\
\hline $2 ; 8$ & 3 & I 2 & $4 \cdot 0$ \\
\hline $2 ; 9$ & 7 & $3 \mathrm{I}$ & $4 \cdot 4$ \\
\hline $2 ; 10$ & I I & $5^{8}$ & $5 \cdot 3$ \\
\hline 2 ; I I & 12 & 50 & $4 \cdot 2$ \\
\hline $3 ; \mathrm{I}$ & 6 & $3 I$ & $5 \cdot 2$ \\
\hline $3 ; 3$ & I I & 77 & $7 \cdot 0$ \\
\hline
\end{tabular}

narratives throughout the year and increased considerably in the last months (see Figure 2).

As repetitions of the same event were numerous in the data, Table 3 offers the average frequencies of DISTINCT reported events per narrative produced over time for each girl. In this table, proto-narratives (narratives with one or zero events) were excluded. There was a clear progression for both girls towards representing a larger number of distinct events in their narratives. The fact that children this young can incorporate as many as seven events in their narratives is impressive. Of course, we need to remember that these were heavily scaffolded intra-conversational narratives and, for the vast majority, relying on shared knowledge between the child narrator and the interlocutor. However, all events included in this table were either spontaneously produced or elicited without being previously mentioned either by the child herself or her interlocutor, and thus all constituted 


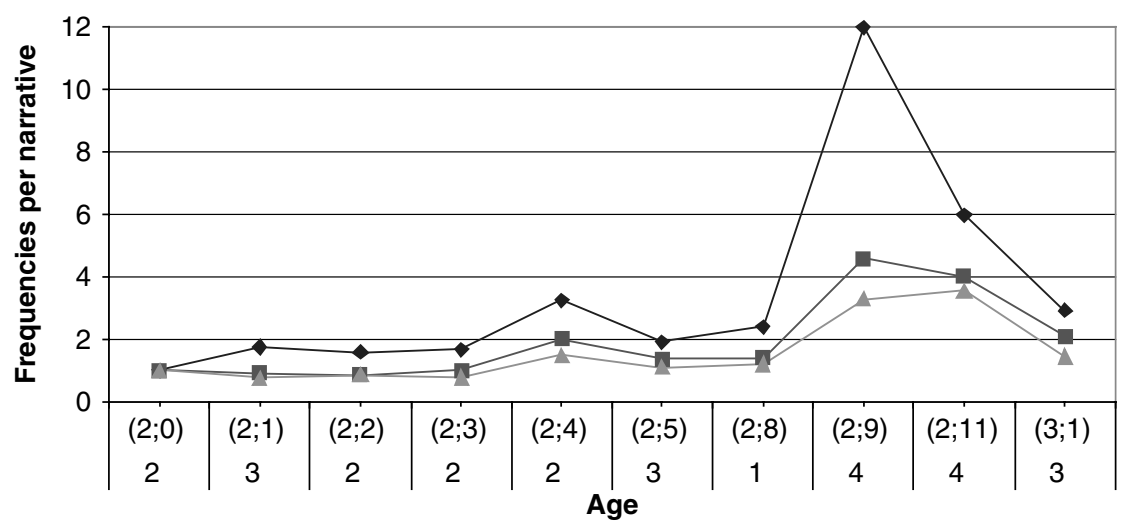

Diversity of past tense/aspect inflections

- Past tense verb tokens $\longrightarrow$ - Past tense form types $\longrightarrow$ Past tense stem types

Fig. 3. MARIA: Past tense verbs: tokens, form types and stems per narrative.

instances of new information provided by these young narrators. Children produced two-event narratives from the beginning of their third year and included, over time, on average, as many as four (María) or seven (Isabella) events per narrative. They engaged in talk not only about the immediate past, but also about events that occurred hours or even days before the moment of speech from the beginning of data collection. Indeed, these narratives about a DISTANT past comprised the most frequent narrative discourse throughout the entire third year covered by both datasets (for details on the uses of past tense forms to refer to immediate or distant past see Uccelli (2003: 6r)). Thus, in the context of spontaneous conversations with familiar adults, these children referred to past events starting as young as age $2 ; 0$.

\section{Lexico-grammatical measures}

Past-tense verbs. As shown in Figures 3 and 4 for María and Isabella respectively, initially the frequency of past tense verbs increased at a very slow pace. Most sessions displayed, on average, a TOKEN FREQUENCY of one to three past tense verbs per narrative, only two or fewer VERB STEMS, and basically one VERB FORM TYPE PER STEM TYPE, signaling minimal morphological variety of past tense usage. ${ }^{8} \mathrm{~A}$ salient change in the production of

[8] Isabella's session at age 2;7 constitutes an exception to this low-frequency pattern. This session, however, contained many repetitions of the same past tense verbs and shared with all the remaining early sessions the low morphological flexibility of basically one form per stem and only two stems per narrative. 


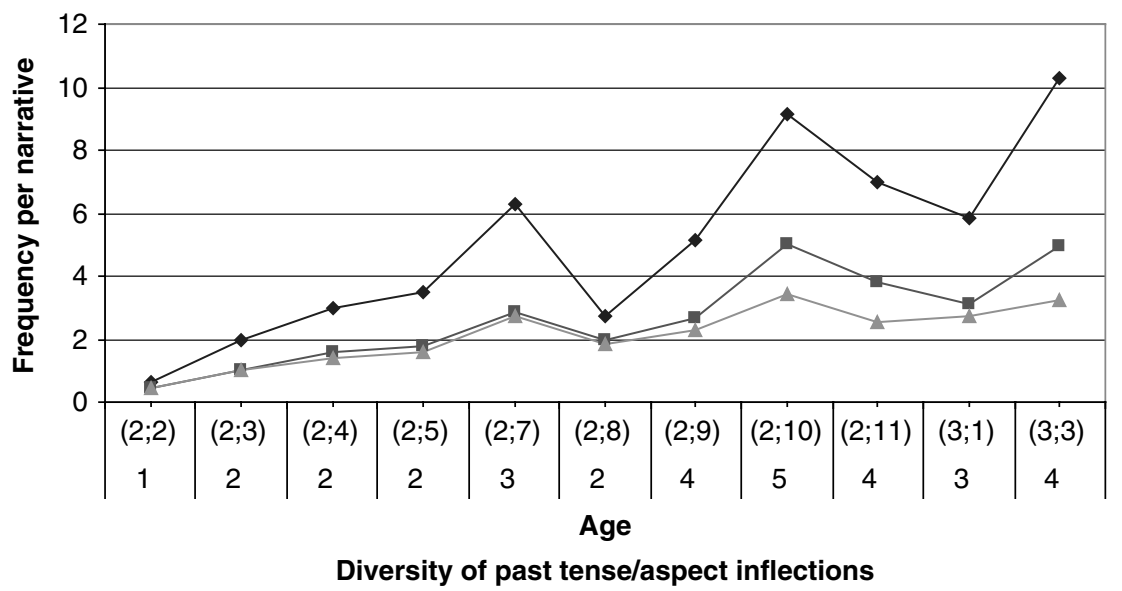

Past tense verbs (tokens) - Past tense verb form types $\rightarrow-$ Past tense verb stems

Fig. 4. ISABELLA: Past tense verbs: tokens, form types and stems per narrative.

past tense verbs emerged later, starting at age 2;9 for María and age 2; io for Isabella. During these sessions, the observed trajectories displayed a sudden growth spurt, with narratives reaching averages of $I 2 \cdot I$ and $9 \cdot 1$ past tense verbs per narrative, respectively. Similarly, the frequencies of verb form types and stems also increased considerably and the gap between these two frequency trajectories widened for the first time for both girls. During these last months there were always more than three verb form types per narrative and in some sessions as many as five, and the number of different verb stems fluctuated between 2.5 and 3.6 per narrative.

This substantial increase in tokens, verb form types and stems per narrative reveals a more advanced mastery of past tense morphology in narrative production during these last months. The higher morphological flexibility displayed by these narratives resulted in large part from a higher diversification in past tense/aspect combinations per narrative.

Interestingly, not only did both girls produce mostly the same forms of past tense/aspect inflections, but also the order in which they incorporated new forms into narrative discourse tended to coincide. Table 4 offers a summary of María's and Isabella's diversity of past tense/aspect forms divided into three phases. The use of past tense/aspect can be summarized as a first phase characterized by minimal presence or diversity of past tense verbs; a second one, in which most narratives displayed past tense verbs and a few emerging contrasts between perfective and imperfect past forms; and a third one, in which all narratives displayed a comparably higher frequency of past tense verbs, and exhibited contrasts between 
TABLE 4. Diversity of past tense/aspect forms : three phases

\begin{tabular}{lll}
\hline & \multicolumn{1}{c}{ Maria } & \multicolumn{1}{c}{ Isabella } \\
\hline \multirow{2}{*}{ PHASE I $^{*}$} & PRESENT PERFECT & PRETERITE \\
& IMPERFECT* & IMPERFECT* \\
& PRESENT PERFECT & PRETERITE \\
& IMPERFECT & IMPERFECT \\
& (PRETERITE) & (PRESENT PERFECT) \\
& & (PAST SUBJUNCTIVE) \\
PHASE 3 & PRESENT PERFECT & PRETERITE \\
& IMPERFECT & IMPERFECT \\
& PRETERITE & PAST SUBJUNCTIVE \\
& IMPERF. PROGRESSIVE & IMPERF. PROGRESSIVE \\
& & IMPERF. PROSPECTIVE \\
& & (PAST PERFECT) \\
\hline
\end{tabular}

* IMPERFECT: During Phase I, the imperfect was expressed only by a few verb forms always used in the same form (estaba, era, tenía) and in no other tense.

perfective/imperfect and progressive/non-progressive past forms, with single narratives including as many as four distinct tense/aspect inflections.

Towards the end of their third year, these young narrators, in addition to a sustained use of past tense forms, selected from among a variety of inflections that offered supplementary aspectual information, i.e. various perspectives on the course of past actions. The same forms were generally produced by both girls, with the most salient difference being the preference for either present perfect (María) or preterite (Isabella) associated with each girl's regional variety. While not all past forms of the Spanish verbal paradigm were present in these data, a significant proportion of them was produced. In line with Sebastián \& Slobin's (r 994) findings, only the perfective progressive was absent from these performances (the pluperfect - or past perfect - was produced once by Isabella).

To illustrate the types of verbs children used with past tense inflections in their narratives, the fifteen most frequently used verb stems were identified for each child. Interestingly, ten out of the fifteen verb stems were the same for both children. Table 5 displays these ten verb stems along with the past tense inflections they displayed throughout the year.

These verb stems refer either to perceptually salient actions or to states. All stems referring to perceptually salient actions displayed at least two - and up to four-distinct past tense inflections that were eventually used successfully to mark aspectual contrasts. Recent research suggests that perceptually salient words, with higher imageability and individuability, tend to be learned before more abstract ones (Hirsh-Pasek \& Golinkoff, 2006). Perhaps, perceptual salience - combined with frequency and discourse context-contributes also to the initial conceptualization of aspectual contrasts 
TABLE 5. Most frequent verb stems with past tense inflections in Maria's and Isabella's intra-conversational narratives

\begin{tabular}{|c|c|c|}
\hline & Maria & Isabella \\
\hline estar ('to be', 'temporary') & imperfect & imperfect \\
\hline $\operatorname{ser}$ ('to be', 'permanent') & $\begin{array}{l}\text { imperfect, present perfect, } \\
\text { (preterite) }\end{array}$ & imperfect, (preterite) \\
\hline haber ('to be', 'impersonal') & imperfect & imperfect \\
\hline $\operatorname{decir}$ ('to say') & present perfect, preterite & preterite, imperfect \\
\hline caer(se) ('to fall down') & $\begin{array}{l}\text { present perfect, preterite, } \\
\text { imperfect progressive }\end{array}$ & preterite, (past subjunctive) \\
\hline hacer ('to do') & present perfect, imperfect & preterite, imperfect \\
\hline comer ('to eat') & $\begin{array}{l}\text { present perfect, imperfect, } \\
\text { imperfect progressive, } \\
\text { preterite }\end{array}$ & $\begin{array}{l}\text { preterite, imperfect, imperfect } \\
\text { progressive }\end{array}$ \\
\hline ir ('to go') & preterite, imperfect & $\begin{array}{l}\text { preterite, imperfect, past } \\
\text { subjunctive }\end{array}$ \\
\hline llorar ('to cry') & $\begin{array}{l}\text { present perfect, imperfect, } \\
\text { imperfect progressive }\end{array}$ & $\begin{array}{l}\text { preterite, imperfect, imperfect } \\
\text { progressive }\end{array}$ \\
\hline venir ('to come') & preterite, imperfect & preterite, imperfect \\
\hline
\end{tabular}

NOTE: Parentheses indicate infrequent occurrences (three or less) of a specific verb stem/past tense combination.

TABLE 6. Frequencies of past tense/aspect forms in parental speech directed to children

\begin{tabular}{|c|c|c|c|c|}
\hline \multirow[b]{2}{*}{$\begin{array}{l}\text { Combined sessions (age } 2 ; 2 \\
\text { and age } 2 ; 3 \text { ) }\end{array}$} & \multicolumn{2}{|c|}{ María's parents } & \multicolumn{2}{|c|}{ Isabella's parents } \\
\hline & $\begin{array}{l}0.52(23) \\
0.09(4) \\
0.34(15) \\
0.05(2)\end{array}$ & $\begin{array}{l}\text { Present perfect } \\
\text { Preterite } \\
\text { Imperfect } \\
\text { Other }\end{array}$ & $\begin{array}{l}00.00 \\
0.73(207) \\
0.24(69) \\
0.03(2)\end{array}$ & $\begin{array}{l}\text { Present perfect } \\
\text { Preterite } \\
\text { Imperfect } \\
\text { Other }\end{array}$ \\
\hline
\end{tabular}

within past tense inflections. Interestingly, the more abstract state verbs, despite their high frequency, either were used exclusively in one past tense form (estar, haber-imperfect) and/or still displayed unconventional uses of present tense in past-anchored narratives at the end of data collection (ser, estar). Whether this is related to their less perceptually salient nature, however, could only be confirmed by further research on the role of imageability in tense/aspect acquisition.

Differences in language varieties. The preferential use of either present perfect or preterite as the initial and most frequent form to express pastness (both immediate and distant past) in narratives was related to language patterns in each girl's language variety. This was confirmed by a brief analysis of child-directed talk. As shown in Table 6, the divergent preferences of primary past perfective form (present perfect for María; preterite for Isabella) were associated with the frequencies of these forms in parental 


\begin{tabular}{|c|c|c|c|c|c|c|c|c|c|c|c|}
\hline $\begin{array}{l}\text { Order of } \\
\text { appearance }\end{array}$ & $2 ; 0$ & $2 ; I$ & $2 ; 2$ & $2 ; 3$ & $2 ; 4$ & $2 ; 5$ & $2 ; 8$ & $2 ; 9$ & 2 ; I I & $3 ; \mathrm{I}$ & TOTAL \\
\hline entonces & & 2 & & & & 4 & & & I & & 7 \\
\hline después & & & I & I & & & & & I & & 3 \\
\hline cuando & & & & 3 & & I & & 2 & 2 & I & 9 \\
\hline hoy & & & & I & & & & & I & & 2 \\
\hline luego & & & & & & I & & & & & I \\
\hline ayer & & & & & & I & & & & & I \\
\hline ahora & & & & & & & I & & & 2 & 3 \\
\hline siempre & & & & & & & I & & & & I \\
\hline un día & & & & & & & I & & & & I \\
\hline otra vez & & & & & & & 2 & & & I & 3 \\
\hline$y a$ & & & & & & & I & 4 & & I & 6 \\
\hline primero & & & & & & & & I & & & I \\
\hline una vez & & & & & & & & & 2 & & 2 \\
\hline antes & & & & & & & & & & I & I \\
\hline esta mañana & & & & & & & & & & I & I \\
\hline mañana & & & & & & & & & & I & I \\
\hline TOTAL & $\circ$ & 2 & I & 5 & $\circ$ & 7 & 6 & 7 & 7 & 8 & 43 \\
\hline
\end{tabular}

child-directed speech. Higher frequencies of exposure to present perfect vs. preterite forms resulted from patterns of use characteristic of each child's Spanish variety combined with the frequency of participation in certain narrative subgenres. For further analysis see Uccelli (2003).

Temporal/aspectual markers. In Tables 7 and 8 the order of markers in the first column follows the order of appearance in the data for each girl. From the total of twenty-six types observed, ten types were produced by both girls. In line with previous research, the most common shared markers were cuando 'when', entonces 'then', ya 'already', después 'then/after' and otra vez 'again'.

Even though temporal/aspectual markers were not present in all narratives, both girls were able to convey a range of temporal/aspectual meanings via a limited but varied set. The most common temporal/aspectual meanings conveyed by both girls were: temporal relations of posteriority, anteriority and simultaneity; and aspectual meanings of recurrence, completion and achievement. However, the order in which these forms and meanings made their appearances in narrative clauses varied. During the initial exploration of certain form/meaning correspondences, these girls preferred contrasting entry points. María initially used temporal connectives and adverbs in syntactically accurate contexts but without clear meanings. From this entry point - characterized as 'use before meaning' (Nelson, i 996) - María progressed towards expressing clear temporal meanings via the previously EMPTY forms. Isabella, on the contrary, seemed to go from meaning to form, using meaningful ASPECTUAL expressions in isolated syntactic contexts, 
TABLE 8. Isabella's temporal/aspectual markers by age and order of appearance

\begin{tabular}{|c|c|c|c|c|c|c|c|c|c|c|c|c|}
\hline $\begin{array}{l}\text { Order of } \\
\text { appearance }\end{array}$ & $2 ; 2$ & $2 ; 3$ & $2 ; 4$ & $2 ; 5$ & $2 ; 7$ & $2 ; 8$ & $2 ; 9$ & $2 ; 10$ & $2 ;$ II & $3 ; \mathrm{I}$ & $3 ; 3$ & TOTAL \\
\hline$Y a$ & I & & & & 2 & 3 & & 5 & I & I & 5 & I 8 \\
\hline otra vez & & IO & I & I & 2 & I & 3 & I & I & & 4 & 24 \\
\hline mañana & & 2 & I & I & I & & & & & & & 5 \\
\hline nunca & & & & 2 & & & & & & & & 2 \\
\hline todavía & & & & & & & I & & I & & & 2 \\
\hline antes & & & & & & & & 4 & & I & & 5 \\
\hline después & & & & & & & & 2 & 8 & 7 & IO & 27 \\
\hline entonces & & & & & & & & 2 & 2 & & & 4 \\
\hline hoy & & & & & & & & 2 & & & & 2 \\
\hline primero & & & & & & & & I & 2 & & & 3 \\
\hline ahora & & & & & & & & I & & I & & 2 \\
\hline no habia tiempo & & & & & & & & I & & & & I \\
\hline de noche & & & & & & & & I & I & & & 2 \\
\hline un ratito & & & & & & & & I & & & & I \\
\hline Ese día & & & & & & & & & I & & & I \\
\hline de momento & & & & & & & & & I & & & I \\
\hline cuando & & & & & & & & & & 4 & & 4 \\
\hline росо а росо & & & & & & & & & & I & & I \\
\hline muchas veces & & & & & & & & & & & I & I \\
\hline hoy día & & & & & & & & & & & I & I \\
\hline TOTAL & I & I 2 & 2 & 4 & 5 & 4 & 4 & $2 \mathrm{I}$ & I 8 & I 5 & $2 \mathrm{I}$ & 107 \\
\hline
\end{tabular}

gradually incorporating these forms into increasingly complex sentences. Her first temporal setting clauses included pseudo-subordinated clauses that only later included the connective in a full-fledged sentence:

MOTHER: ¿Cuándo fue eso?

'When was that?'

CHILD: Que vino Nico.

'That Nico came.'

MOTHER: ¿Cuando vino Nico?

'When Nico came?'

CHI : Sí.

'Yes.'

(Isabella, $2 ;$ 10)

Developmental co-occurrences. When looking simultaneously at the analytical dimensions of past tense usage and narrative components, it became evident that the progress in the use of past tense inflections occurred mostly in the context of EvENT $^{9}$ clauses (as opposed to evaluation or setting). More

[9] When written in capital letters EVENTS refer exclusively to the foregrounded events reported in EVENT clauses and should be distinguished from the common meaning of events as any happening or occurrence. 


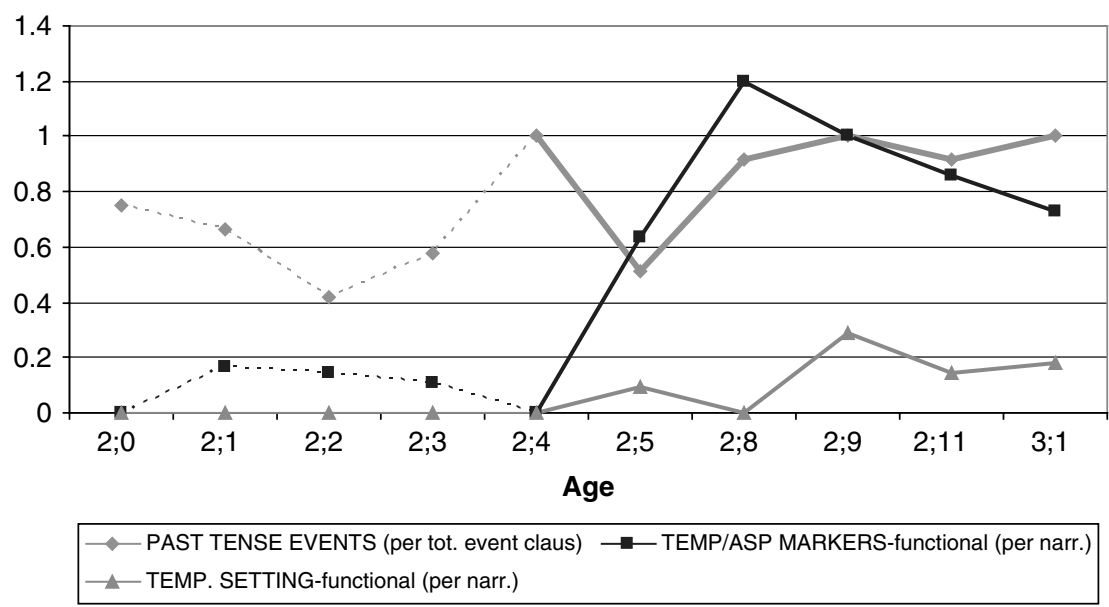

Fig. 5. MARIA: Grammatical and discourse skills used in expression of temporality.

interestingly, once the consolidation in the use of past tense inflections to report EVENTS was achieved, an explosion of forms, both in frequency and diversity of TENSE/ASPECT INFLECTIONS, TEMPORAL MARKERS and TEMPORAL SETTING occurred. During the first months children would report EVENTS via unclear, non-linguistic or non-past forms, but eventually both started using a past tense form for every single reported EVENT (although this was still not the case for setting or evaluation). At this point children seem to have established a connection between past foregrounded EVENTS and perfective past tense. This crucial linguistic/cognitive achievement constituted a milestone that seemed to facilitate the acquisition of subsequent linguistic forms to express temporal relations.

In Figures 5 and 6 the lines labeled PAST TENSE EVENTS display the number of EVENT clauses with past tense verbs divided by the total number of EVENT clauses. If all EVENTS were reported via a past tense verb, a straight line would indicate a ratio of one-to-one for EVENTS and past tense verbs. The fact that the line does not reach one during the early months reflects children's use of other means to report EVENTS, namely non-verbal resources (i.e. enactment, sound effects), unclear forms and nonpast forms (i.e. present tense, non-personal forms). When the line becomes solid, the graph shows the point at which children achieved the consolidation of past tense to report EVENTS. From that point on, the gaps observed correspond to narratives anchored in the present tense, but all other narrative EVENTS were reported via past tense. As these figures show, once EVENTS were consistently reported via past tense verbs, the production of temporal markers and temporal setting exhibited unprecedented 


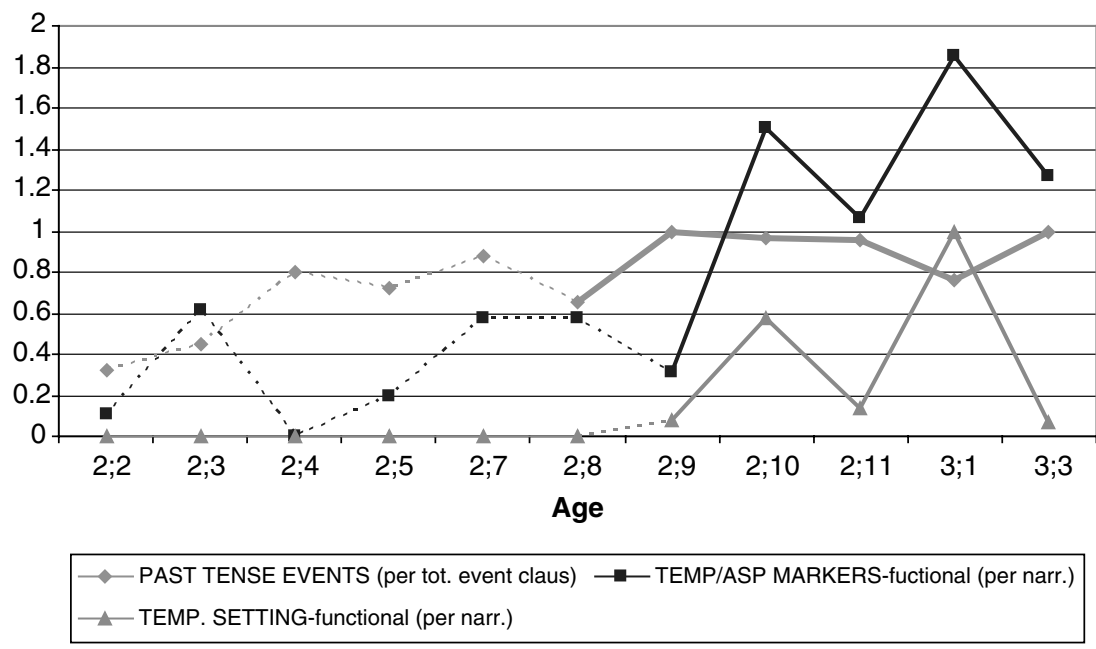

Fig. 6. Isabella: Grammatical and discourse skills in the expression of temporality.

increases. These figures illustrate the explosion of temporal forms occurring during the last months of the third year simultaneously or subsequently to the achieved consistency of past tense to report EVENTS. Not only did temporal markers and temporal setting clauses increase, but also the variety of past tense/aspect inflections increased considerably, as explained above. Although the ages at which this consolidation was achieved varied between ages 2;4 and 2;5 for María and ages 2;8 and 2;9 for Isabellageneral patterns of co-occurring or immediately subsequent developmental changes in the production of other means to express temporality coincided for both girls.

Developmental co-occurrences across- and within-child can be summarized in three phases: (I) a preferred but inconsistent use of perfective past tense for EVENT clauses with minimal presence of either EMPTY connectives (María) or ASPECTUAL markers (Isabella); (2) a move towards consistent use of perfective tense for EVENT clauses and mostly present tense to report evaluation; and finally (3) an explosion of forms characterized by a consistent use of past tense for EVENT clauses, an increasing, though not always consistent, use of past tense for setting and evaluation, and a considerable increase in frequency and variety of past tenses and temporal/aspectual markers, as well as the emergence of temporal setting. Among the different skills displayed over time, the consolidation of the use of past tense to report EVENT clauses marked an important developmental point for both girls that triggered an explosion of co-occurring developmental skills. 
The following section describes these three phases, illustrating them with examples.

THREE DEVELOPMENTAL PHASES: A QUALITATIVE PORTRAYAL

Phase I : alternative means to report past events

The preference for past tense usage to report narrative EVENTS was evident for both girls even at this early phase. In seven out of ten sessions for María, and in nine out of eleven sessions for Isabella, more than $60 \%$ of all EVENT clauses were reported via perfective past tense. Despite this overall preference, the use of past tense to report EVENTS was far from consistent. During these first months approximately one-third of all EVENTS were reported via: (a) non-verbal means - such as gestures or sound effects; (b) unclear forms; or (c) non-past verb forms - present tense verbs or non-personal verb forms. Here are some examples.

(a) Non-verbal events. These elicited narratives include gestures and sound effects as strategies for conveying events. Probably, the lack of a lexical item to refer to the targeted actions was the underlying cause for using these non-verbal means.

FAT: ¿Qué le cantaron a Ludovico hoy?

СНI: beye+tuyu, beye+tuyu, beye+tuyu [\% child sings].

CHI : $\circ$ [child claps].

FAT: ¿¿ todos aplaudieron al final?

\section{¿Y qué hizo Ludovico?}

CHI : [child blows as if blowing a candle].

FAT: ¿Cómo se dice eso?

CHI : $\quad x x$ (UNC) veya [:vela].

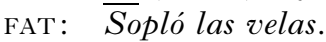
¿Cuántas velas habia?

CHI : Una.

FAT: Una.

CHI : aiendo [=?comiendo] (UNC, PROG ?) tota [:torta], alli tota [:torta].

MOT: ¿Comiste torta?

CHI : Sí.
'What did you sing to

Ludovico today?

beye tuyu, beye tuyu, beye tuyu

[\% child sings].

$\circ$ [child claps]. $\longrightarrow$ NON-VERBAL EVENT

'And everybody clapped at the end?'

'And what did Ludovico do?' [child blows]. $\longrightarrow$ NON-VERBAL EVENT

'How do you say that?' ' $\mathrm{xx}$ (UNC) candle.'

'[$\overline{\mathrm{H}} \mathrm{e}]$ blew the candles.' 'How many candles were [there]?' 'One.'

'One.'

'aing [=? eating] (UNC, PROG ?)'

'cake, there cake.'

'You ate cake?'

'Yes.'

(Isabella, 2;2) 
Isabella found alternative strategies to convey meanings that still surpassed her lexico-grammatical skills. Through non-verbal enactments and sound effects she was able to report distinct components of a past anecdote. This narrative exchange also illustrates the opportunities for learning verbs in conversational narratives. In most instances, immediately after the enactment, the interlocutor produced the corresponding past tense verb phrase providing the linguistic forms that matched the communicative intent of the child.

(b) Unclear forms. The following example displays two unclear forms in the co-narration of a vicarious experience.

$\mathrm{CHI}: \quad$ Me ágo (UNC).

мот: ¿Te ahogas? ¿Quién te ha enseñado a ti?

CHI: No. Con un camelo [:caramelo].

мот: ¿Con un caramelo, te ahogas?

CHI : Si. Estaba (IPFV) una niña, ¿̨a qué sí?

мот: Sí. ¿Dónde?

CHI : No sé. En misa.

мот: Sí.

CHI : En misa.

мот: Hay una niña que por poco se ahoga, ¿verdad hija?

CHI : Sí. Co, co u camelo.

мот: Fíjate, creo que sólo ha oído la palabra ahogo una vez.

CHI: No! Una ni, una niña, ¿̇a qué sí?

мот: Claro.

CHI : Claro. Se se sa solo (UNC) a llorar.

мот: Se puso a llorar.

CHI: Sí.
'[I] xx (UNC).'

'Did you choke? Who has taught you?'

'No. With a candy.'

'With a candy you choke?'

'Yes. There was (IPFV) a girl, right?'

'Yes. Where?'

'I don't know. At Mass.'

'Yes.'

'At Mass.'

'There is a girl that almost chokes, right daughter?'

'Yes. Wi, with a candy.'

'See, I think that

[she] has heard the word choke once.'

'No! A gi, a girl, right?'

'Of course.'

'Of course. [She] $\mathrm{xx}$

(UNC) to cry.'

'[She] started to cry.'

'Yes.'

(María, 2;2)

The forms María used to report EVENTS were not past tense verbs, but unclear forms that her mother translated into conjugated verbs.

(c) Use of non-past forms. Non-personal forms (i.e. progressives and infinitives) and present tense were also used to report events during 
this phase:

FAT: Di lo que has hecho a mamá

[\% child is silent].

Venga, diselo ¿qué has hecho?

CHI : $\quad$ [\% child makes an angry face $]$.

FAT: ¿Qué has hecho?

$\mathrm{CHI}$ : ompiendo [:rompiendo] (PROG) las plantas.

FAT: ¿El qué?

CHI: Las plantitas.

FAT: ¿El qué?

¿Qué le has hecho a las plantitas?

CHI: Aqui, en el suelo.

FAT: Claro, ¿qué ha hecho mamá?

CHI : O [?] regaña (PREs).(...)
'Tell what [you] have done to your mother.'

[\% child is silent].

'Come on, tell her what have [you] done?'

○ [ $\%$ child makes an angry face].

'What have you done?'

'breaking (PROG)

the plants.'

'What?'

'The little plants.'

'What?'

'What have you done to the little plants?'

'Here on the floor.'

'Of course, what did mom do?'

'Or [?] [she] scolds (PREs). $(\ldots)$

(María, 2; I)

CHI: Beya [:Isabella] peya [:pega $]$ (PRES)

ati [:así] Daneya ati [:asi] mano.

мот: ¿En la mano? ¿Quién pegó?(...)

CHI: $A$ mí.

MOT: ¿Daniela?

CHI: No a mí.

мот: ¿¿Tú le pegaste? ¿Por qué, gorda?

$\mathrm{CHI}$ : Lloyó [:lloró] (PFV).
'Beya [:Isabella] hits (PREs)

[like] this Daneya [like] this

hand.'

'On the hand? Who hit?'

'Me.'

'Daniela?'

'Not me.'

'You hit her? Why, dear?'

'Cried (PFV).'

Progressive forms, such as rompiendo 'breaking', convey information about the course of the actions, i.e. the aspectual nature of the actions, rather than information about their temporal location. María might be focusing on the durative/iterative aspect of the action of breaking, instead of locating it in the past. In the cases of regaña 'scolds' and pega 'hits' it is harder to speculate about the motivation. Notice that in other cases, such as lloró 'cried', the past tense is used. It seems that at this phase, children were still struggling to convey basic meanings without yet making consistent choices of tense. 
Additional strategies. Two additional resources were identified during this phase: ( $\mathrm{I}$ ) the child's assent in response to her interlocutor's yes/no questions about a past event (a conversational pattern reported by Eisenberg (1985)); and (2) the use of speech, either in the form of actual 'quotes' or in the form of songs that took place at the moment of the reported anecdote. These strategies remained part of children's narrative performance throughout the year but later were combined with full-fledged event clauses and used mostly as additional support instead of main carriers of narrative content. In the next example María conveyed almost the entire narrative via speech clauses that reported what was said at the moment of the anecdote (speech clauses are underlined). Only the last unclear clause is not a speech clause. Initially her aunt prompted María for an event clause, but the child responded with a speech clause. Her father continued the interaction via a general request, but then he followed the child's lead and prompted her for a speech clause.

AUnT: ¿Qué hiciste al Yayito con la tele?

CHI: Quitalo (IMP).

FAT: Aver, cuéntame.

CHI : Págalo [:apágalo] (IMP).

FAT: Cuéntamelo más.

CHI: Págalo [:apágalo] (IMP).

FAT: ¿̇Elqué?

CHI : Págalo (IмP) la tele Yayito.

FAT: ¿¿Por qué?

CHI: Poque sí.

FAT: ¿̨Y qué dijo el Yayito?

CHI : Pos que no.

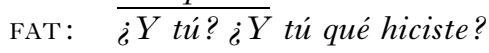

CHI : $\quad x x(\mathrm{UNC})$ en e culo.
'What did you do to Yayito with the TV?'

'Stop it (IMP).'

'Let's see, tell me.'

'Turn it off (IMP).'

'Tell me more.'

'Turn it off (IMP).'

'What?'

'Turn it off (IMP) the TV

Yayito.'

'Why?'

'Just because.'

'And what did Yayito say?'

'Well that no.'

'And you? What did you do?'

'xx (UNC) on the butt.'

(María, 2; I)

By directly quoting direct speech without even using a verb of diction to introduce it, children were able to advance the plot adding new developments to the anecdote. These strategies illustrate children's search for alternative resources to report meaning that might still surpass their grammatical skills.

During this phase, despite some unanalyzed uses of imperfect, such as estaba, setting and evaluation clauses were conveyed mostly via verbless 
clauses that tended to occur as responses to elicitation questions:

AUNT: ¿Dónde has estado este verano? (...)

CHI: En Galisia [:Galicia]. AUNT: ¿¿Y qué tal lo has pasao?

CHI : Bien.
'Where have you been this summer?'

'In Galicia.'

'And how was it?'

'Good.'

(María, 2; I)

In conclusion, at this early phase, even though the majority of events were reported via past tense verbs, approximately onethird of them were expressed via non-verbal means, unclear forms, nonpersonal forms and present tense verbs. Evaluation and setting were mostly conveyed via verbless clauses, and were often prompted by adult questions.

\section{Phase 2: transition towards consistency}

This transition phase is characterized by progress towards the consolidation of the use of past tense verbs to report events. It constitutes a transitional moment in which both girls still produced some narratives without tensed verbs, yet also produced for the first time a few narratives with as many as seven past tense verb form types. There is one instance of a non-personal form produced by each girl to report an event, signaling the transitional nature of this moment. From 2;5 on for María, and from 2;8 on for Isabella, all EVENT clauses were consistently reported via tensed verbs and mostly via past tense verbs.

The distinction between perfective and imperfective started to be evident with just a few but meaningful uses of imperfect to mark past actions' contours, in particular, the aspectual meanings of duration and iteration:

Durative: $\quad$ Caperucita se iba (IPFv) por el bosque. (María, 2; 5)

'Little Red Riding Hood was leaving through the woods.'

Iterative: $\quad$ Tiraba (IPFV) todo a [:al] piso. (Isabella, 2;8)

'[She] was throwing everything to the floor.'

Durative/Iterative: Comía (IPFv) todo. (Isabella, $2 ; 8$ )

' $\mathrm{He}]$ was eating everything.'

Within this phase each girl produced one contrastive aspectual use, i.e. the same verb stem in perfective and imperfective form. Isabella used the forms sonó and sonaba in a conventional manner to refer to a completed punctual action and an incomplete durative action, respectively. María's aspectual contrast with constiparse was not clear because she used se ha constipado and se constipaba in an invented plot to refer to what seemed 
foregrounded punctual events. Thus, a few functional uses of the imperfect co-occurred with some less clear cases. The functional instances, though, seem to anticipate that the first aspectual distinction to emerge within a past perspective was perfective vs. imperfective. It is important to highlight, however, that isolated contrastive uses do not imply a productive mastery of the imperfect tense.

Between ages 2; 5 and 2;8, both girls produced the alternative form of perfective past (preterite for María, ${ }^{\mathbf{1 0}}$ and present perfect for Isabella). For Isabella it was only a single instance, however for María this phase constituted the emergence of the use of the preterite in her fictional narratives. Her uses reflect a still incipient presence of the preterite: only four tokens were identified during this phase, most of them produced in the context of what seems a memorized minimal story.

Verbless clauses still constituted an important presence, but now as many as $50 \%$ of evaluation clauses (for María, $40 \%$ for Isabella) were expressed via present tense verbs. Still, past tense was the least used means for evaluation. Verbless clauses continued to be the main means used by both girls to express setting.

In sum, during this transition phase children moved from using non-conventional means to report events to producing past tense verbs in most narratives, but without yet consistently sustaining a past perspective for reporting events. The frequency of past tense forms slowly increased during this phase, and the distinction between perfective and imperfective started to surface in just a few uses that denoted either duration or iteration.

\section{Phase 3: explosion of forms}

During the last months, these young narrators consistently reported all narrative EVENTS via past tense verbs, with the only exception of narratives anchored in the present tense. Narratives displayed a sustained sequence of past tense verbs, but a few illustrated the still ongoing struggles with the use of past tense/aspect to report evaluation and setting.

These narratives were the longest and most complex performances in the dataset, signaling an advancing ability to sustain a past perspective. EVENTS were consistently reported via past tense, and new perspectives were combined with the perfective option used almost exclusively in previous phases. Indeed, the panorama clearly changed from a monotonous rendition of EVENTS basically dominated by the present perfect for María, and the preterite for Isabella, with occasional uses of the imperfect, to narrations that combined as many as four distinct past tenses. In the

[ı。] Only two isolated productions of the preterite had been recorded for María, one at age 2; I: no se fue; and one at age 2;3: vinió el lobo. 
narratives of the last three months, the preterite shared the narrative space with the imperfect (and with the present perfect for María), and an imperfect progressive (plus a prospective imperfect only for Isabella) offered yet additional perspectives on the course of past actions. While the anticipated perfective/imperfective distinction from previous months became consolidated, the next aspectual contrast was progressive vs. non-progressive past actions. The following example displays a set of multiple shifts in tense/aspect that mark effective contrasts. Functional tense shifts occurred from past to present tense to distinguish event vs. speech clauses, respectively; and imperfect progressive, perfective and imperfect were used to mark different perspectives on past actions: durative, completed/punctual or iterative contours. ${ }^{11}$

CHI: Y yo estaba, yo estaba, yo estaba jugando (IPFV.PROG) con mis piezas y me estaba alacando (IPFV.PROG)

[:arrancando]esa pieza, iasi, asi!

MOт： ¿Así te las arrancaba(IPFv)

de tu mano?

CHI : iSi!

Mот: ¿¿Y tú qué hiciste (PFv)?

CHI: Yo e poni (PFV-overreg) y Abri me quitó (PFv) ota vez

y yo dijo (PFV-3rd p.sg):

"Me das (PREs-2nd p.sg.) esa pieza por faló [:favor]",

y Abri me quitaba (IPFV)

asi

y no me decía (IPFV) por

faló [:favor]!
'And I was, I was

I was playing (IPFV.PROG)

with my [puzzle] pieces

and [she] was pulling

(IPFV.PROG) [away]

that piece from me, [like] this, [like] this!'

'[Like] this [she] was pulling (IPFV)

them away from your hand?'

'Yes!'

'And what did you do (PFV)?'

'I put (PFV-overreg) it

'and Abri took (PFv) it away again

and I said (PFv-3rd p.sg):

"Give (PREs-2nd p.sg.) me

that piece please"

and Abri was taking (IPFV) [it] away

[like] this

and [she] was not telling (IPFV)

me please!'

[II] The following abbreviations were used: PFV perfective (preterite), IPFV imperfective, PROG progressive, PREs present, IMP imperative, PERF perfect (PRES.PERF present perfect; PAST.PERF past perfect), NEG negative, UNC unclear form, 'overreg' overregularization. 
мот: iNo te decía (IPFV) por favor!

CHI: Yo le decía (IPFV) por faló [:favor] $y$ me quitaba (IPFV)

$y$ arranchaba (IPFV)

yo le decía (IPFV) por faló [:favor]

y ella me daba (IPFV)

$y$ me arranchaba (IPFV)

y yo le pedia (IPFV) por

faló [:favor].

мот: $M m$, ¿y entonces qué

hicieron $(\mathrm{PFV})$ ?

CHI: Y Ima [:Irma] e decía (IPFv)

a Abri

que no se debe (PRES:AUX)

arranchar!

мот: Ahok.

CHI : iY ella hació (PFV-overreg)

ota [:otra] vez!

yo le dije (PFv) por faló [:favor].

Ella me arranchó (PFV).

мот: ¿¿Y qué pasó (PFv)?

$\mathrm{CHI}$ Y Y Ima le lijo [:dijo] (PFv):

“ ¡No hagas (NEG IMP) eso!” (...)
'[She] was not telling (IPFV) you please!'

'I was telling (IPFV) her please and [she] was taking (IPFv) [it] away

and [was] pulling (IPFV) away I was telling (IPFV) her please and she was giving (IPFV) [it] to me

and [she] was pulling (IPFV)

[it] away from me

and I was asking (IPFV) her

(saying) please'

' $\mathrm{Mm}$, and then what did [you] do (PFv)?'

'And Ima was telling (IPFV)

Abri

that [one] should (PREs:AUX) not pull away.'

'Ah OK.'

'And she did (PFV-overreg) again!

I told (PFV) her please.

She pulled (PFV) [it] away

from me.'

'And what happened (PFV)?

'And Ima told (PFv) her:

"Don't do (NEG IMP) that!" $(\ldots)$ '

(Isabella, 3;3)

The most significant change in the production of evaluative clauses was a sudden spurt in the use of past tense to express evaluation, with some sessions exhibiting as many as $65 \%$ (for María) and $75 \%$ (for Isabella) of evaluation clauses with past tense verbs (e.g. y no me decía (IPFv) por faló!). Verbless clauses now constitute the secondary means for expressing evaluation and present tense remains used, although less frequently than in the previous phase. In setting clauses, the use of past tense also increased, although verbless clauses continued to be frequent and for some sessions were still the most prevalent.

Unconventional uses of present tense for evaluation and setting. Towards the end of the year, the children produced a few long and minimally scaffolded narratives. Interestingly, even with the maintenance of past tense 
being a challenge in such autonomous discourse contexts, past tense was consistently used for EVENT clauses. It was in the context of setting or evaluation, that past tense was not consistently used. The following example displays a fragment of Maria's retelling of $E T$, a narrative anchored in the past tense. The complex content combined with the length of the narrative posed a challenging scenario for tense maintenance and María produced some unexplained shifts into present tense in her retelling:

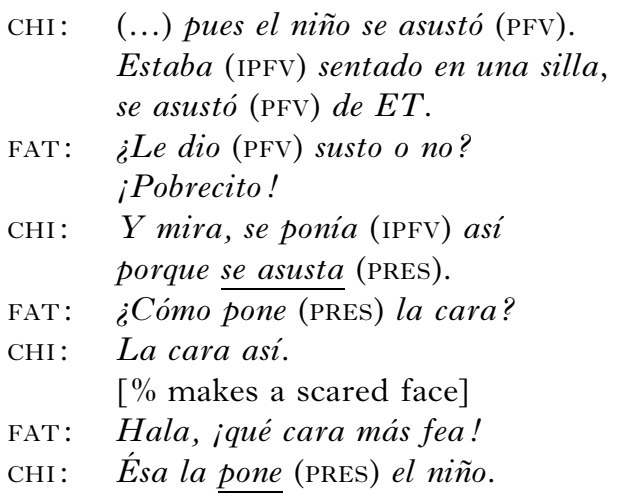

'(...) well the boy got scared.

[He] was sitting on a chair, [he] got scared with ET.'

'[He] got scared or not?

Poor thing!'

'And see, [he] was [like] this because he is scared.'

'What face does [he] make?'

'The face [like] this.'

[\% makes a scared face]

'Wow, what an ugly face!'

'That [face] makes the boy.'

(María, 2;9)

For EVENTS, the child appropriately used past tense, but when she reported evaluation she sometimes shifted into present tense. Unfortunately, these unconventional instances were not sufficient to warrant an analysis of possible discourse-motivated shifts.

In the context of more autonomous performances, setting and evaluation seem to be more vulnerable components, while EVENTS are consistently reported via past tense. Thus, while unconventional uses of tense were minimal after the first half of these girls' third year, it could be expected that as they move towards more autonomous narrative performances, this advance in autonomy would bring with it the new challenge of tense maintenance, particularly in the expression of setting and evaluation.

Diversity and integration of temporal/aspectual markers. Towards the end of their third year, the frequency and variety of markers for expressing temporality in narratives increased considerably for both girls. Two important developmental advances took place: (I) the emergence of temporal setting providing relevant reference time for narrated events; and (2) the integration of distinct temporal markers within clauses and narratives. Children displayed the ability to integrate as many as three (María) or four (Isabella) types of temporal/aspectual markers within a single narrative. These narratives combine reference time markers, aspectual expressions and temporal adverbs offering explicit and relevant temporal information. 
CHI: Cuando, cuando eh era (IPFV) chiquita

decía (IPFV) "patapatatatata" y a poco a poco

habia aprendido (PAST.PERF) $x x$.

мот: Has aprendido

y aprendido cada vez más

¿no gorda?

CHI : Sí.

Despés cumpia(IPFV) un año

$y$ despés cumpia (IPFV) dos años

$y$ despés cumpia (IPFV) tres años.

MOT: Exacto

CHI : Foseantoniete hoy m'a [:me ha] pegao.

M'a [:me ha] pegao (PRES.PERF), $<$ cuando estaba $>$, cuando estaba (IPFV) su marde $\overline{\text { [:madre] }}$ en el jardín.

мот: ¿Si?

CHI : Sí.

мот: ¿¿Y qué hacias (IPFV) alli?

CHI: Pues estaba hablando (IPFV.PROG) con Ma. Carmen

y su madre, y a Foseantonio

y la, y l'a [:le ha] preguntao (PRES.PERF)

a su marde [:madre]:

"Quieres (PRES) jugar con la,

conmigo a la pelota mamá?’”

Eso ha preguntao (PRES.PERF).
'When, when eh [I] was little,

I used to say "patapatatatata" and by little by little

[I] had learned xx.'

[\%com: child refers to the fact that when she was little she could not speak well]

'[You] have learned

and learned more each time, right?'

'Yes.'

'After [that] [I] turned one year,

and after [I] turned two years, and $\overline{\text { after }}$ [I] turned three years.'

'Exactly.'

(Isabella, $3 ;$ I)

'Joseantoniete today has hit me.

[He] has hit me, when [he] was,

when his mother was

in the yard.'

'Yes?'

'Yes.'

'And what were [you] doing there?'

'Well, [I] was talking

to Ma. Carmen

and his mother,

and to Joseantonio

and the, and [he] has asked

his mother:

"Do you want to play ball with the,

with me mom?"

That [he] has asked.' 
мот: Y su mamá ¿qué le ha dicho (PRES.PERF)?

CHI : No, Foseantonio no.
'And his mother, what did [she] say?'

'No, Joseantonio, no.'

(María, 2; I I)

Clearly, not all narratives displayed such skillful integrations. These few examples, however, are illustrations of these children's optimal skills in the expression of temporality via explicit grammatical markers.

\section{CONCLUSIONS}

From two to three years of age, children in this study progressed from scattered and inconsistent linguistic means for encoding pastness to mastering a basic linguistic system that included devices to mark LOCATION of events (past, present and future), TEMPORAL RELATIONS (anteriority, simultaneity and posteriority), and ASPECTUAL MEANINGS (perfective, imperfective, progressive, iterative). Obviously, by age three, they had only acquired a subset of the forms and functions available in their language and they still had much to learn. However, the basic means already acquired by the end of their third year allowed these children to construct narratives with explicit temporal relations successfully conveyed via linguistic expressions.

\section{DISCUSSION}

This analysis illustrates a converging development, with grammar and discourse developing interactively. At the beginning of the year, with still limited grammatical skills, children used not only non-verbal means (e.g. gestures and onomatopoeias), but also REPORTED SPEECH to convey complex narrative content. Children seemed to be searching for forms of expression as the result of their motivation to report what happened. In line with these results, Halliday (I975) has already documented a child aged I;6 spontaneously narrating past happenings to an adult using unconventional and rudimentary linguistic forms. Following Bruner's (I990) argument, this motivation to narrate would push forward grammatical development in that the desire for more accurate reports will lead children to search for more precise grammatical means of expression. In particular, as Nelson ( 1996) has proposed, children's drive to sequence events seems to be a core force stimulating co-occurring grammatical and discourse development. Once new grammatical devices are acquired, children's ability to communicate more complex narratives advances as well. In this way, progress continues, and will continue, as the result of a constant synergic development of skills. 


\section{Developmental co-occurrences}

These data reveal important points of concurrence with Nelson's ( I 989) analysis of Emily's narratives. First, Nelson's claim that linguistic forms lead to the conceptualization of the distinction of past, present and future time is highly relevant. Initially, children in this study used perfective past inflections only partially to report events, and their uses of past tense were far from systematic. We can speculate that during this initial phase perfective forms have come to the children's attention based on their interactions with adults, but the conceptual distinctions of these forms are still under construction (Nelson, I 989; I 996). Once children established the connection between foregrounded EVENTS and perfective past tense, an explosion of temporal skills took place. This initial conceptual/linguistic advance seems to offer a conceptual frame that facilitates the construction of further connections between linguistic forms and their temporal meaning. Now, children start to represent their experientially driven event knowledge - e.g. sequence, duration - with new linguistic devices such as adverbs and connectives. This synchronous development of multiple skills to express temporality indexes an initial basic system of temporality.

\section{Temporal markers and reference time}

As in Nelson's descriptions of Emily's narratives, temporal/aspectual markers were produced as early as the first past perfective forms expressing temporal contrasts emerged. However, the frequency and functionality of these markers dramatically changed after the consolidation of past perfective to express EVENTS was achieved. In line with Smith's ( I 980) original proposal and Weist \& Buczowska's ( 1987 ) model, these young children were able to refer to a time preceding SPEECH TIME (ST) via tense inflections. This study suggests that, within the highly complex Spanish verb paradigm, children focus first on mastering a basic form, i.e. perfective, to express past actions in narratives without explicitly marking other temporal relations. During the initial productive yet not systematic use of past tense marking, the only markers used were either EMPTY connectives or ASPECTUAL markers. Gradually mere juxtaposition and inconsistent past tense gave way to the systematic expression of past EVENTS via perfective and only then did a substantial increase in temporal markers take place. At this point temporal markers were introduced to make temporal relations explicit and reference time emerged, via temporal adverbs, connectives, full clauses and other expressions. In line with Weist's analysis, reference time emerged only between 2;6 and 2;9, when the explosive synchrony of temporal skills took place. The systematic use of the perfective immediately precedes or coincides with the abrupt increase in temporal markers and the emergence of temporal setting, and therefore suggests a temporal system in which ST 
(speech time), ET (event time) and RT (reference time) can be all expressed linguistically for the first time. In accordance with Weist's third phase, children in this study referred only to restricted RT, i.e. that which coincides with ET, and were still not able to refer to flexible RT.

\section{Abundant use of past tense verbs}

First, the distinct past tense inflections - i.e. present perfect vs. preteritepreferred by each child corresponded to the most frequent forms of the language varieties that surrounded each of them.

Second, children in this study produced a high frequency and considerable diversity of past tense verbs during their third year of life. In contrast, several previous studies of Spanish acquisition have reported minimal variety in past tense forms before age three (González, ı 980 ; Peronard, I 987 ; Morales, I 989; Johnson, I996). None of these previous studies focused on narrative discourse, therefore the answer to the discrepancies seems to be found in the context of language production. This analysis points towards narrative as a context that promotes a sophisticated use of grammar, specifically of past tense inflections. These findings are indeed consistent with Sebastián \& Slobin's ( I 994) and Eisenberg's ( 1985 ) studies. It is of the utmost importance to describe discourse context in studies of verb use or acquisition. Without this specification, individual differences as well as contradictory results among studies will remain unanswered. In particular, future comparative analyses of narrative vs. non-narrative discourse are crucial to fully understand how different discourse contexts interact with specific lexico-grammatical skills in the expression of temporality.

Additionally, despite the early contrastive use of perfective tense reported for María by Fernández (I994), it was only at the age of 2;6 that María started to use the past tense consistently to report narrative events. Thus, in line with Shirai \& Miyata's (2006) distinction between the use of contrastive past tense and the use of deictic past, the first contrastive uses of past tense for this girl seem to signal only the beginning of a gradual learning process. In fact, the abundant production of past tense inflections reported in this study is not at odds with a view of a piecemeal acquisition (see Gathercole et al., I 999).

This study underlines the importance of narrative co-construction in development; and it foregrounds the need to study grammatical and discourse progress in an integrative manner, so that children's progress can be fully understood. While the current results are revealing of interconnected phenomena in the development of past reference, they are also limited to only this corner of temporality, without analyzing present, future or conditional reference. Only further research with larger samples could confirm the developmental co-occurrences reported here. These findings offer an initial 
but incomplete account of how temporality develops in Spanish and invite further explorations of the full temporal system.

\section{REFERENCES}

Bakeman, R. \& Gottman, J. M. (1997). Observing interacion: An introduction to sequential analysis. New York, NY: Cambridge University Press.

Bamberg, M. (I997). Narrative development. Six approaches. Mahwah, NJ: Lawrence Erlbaum Associates.

Bates, E., Camaioni, L. \& Volterra, V. (I975). The acquisition of performatives prior to speech. Merrill-Palmer Quarterly 21, 205-24.

Bello, A. (1984). Gramática de la lengua castellana. Madrid: Editorial EDAF.

Berman, R. \& Slobin, D. I. (I994). Relating narrative events : A crosslinguistic developmental study. Hillsdale, $\mathrm{NJ}$ : Lawrence Erlbaum Associates.

Bloom, L., Lifter, K. \& Hafitz, J. (I980). Semantics of verbs and the development of verb inflection in child language. Language 56, 386-4I2.

Brown, R. (1973). A first language: The early stages. Cambridge, MA: Harvard University Press.

Bruner, J. (1990). Acts of meaning. Cambridge, MA: Harvard University Press.

Cartagena, N. (I999). Los tiempos compuestos. In I. Bosque \& V. Demonte (eds), Gramática descriptiva de la lengua española, Vol. 2, 2935-77. Madrid: Espasa Calpe.

De Jonge, B. (1995). El valor del presente perfecto y su desarrollo histórico en el español americano. Paper presented at $V$ Congreso Internacional de "El Español de América", Burgos, Spain.

Eisenberg, A. R. (1985). Learning to describe past experiences in conversation. Discourse Processes 8(2), 177-204.

Fernández, A. (1994). El aprendizaje de los morfemas verbales. Datos de un estudio longitudinal. In S. López Ornat (ed.), La adquisición de la lengua española, 29-46. Madrid: Siglo XXI.

Gathercole, V. C. M., Sebastián, E. \& Soto, P. (I999). The early acquisition of Spanish verbal morphology: Across-the-board or piecemeal knowledge? International Fournal of Bilingualism 3(2-3), I $33-82$.

Gerhardt ( (1989). Monologue as speech genre. In K. Nelson (ed.), Narratives from the crib, I 7 I-230. Cambridge, MA: Harvard University Press.

González, G. (1980). The acquisition of verb tenses and temporal expressions in Spanish: Ages 2,0-4,6. Bilingual Education Paper Series 4(2). Los Angeles: National Dissemination and Assessment Center, California State University.

Halliday, M. A. K. (1975). Learning how to mean: Explorations in the development of language. New York: Elsevier North-Holland.

Hemphill, L., Uccelli, P., Winner, K., Chang, C. \& Bellinger, D. (2002). Narrative difficulties in children with histories of early corrective heart surgery. Fournal of Speech and Hearing Research 45, 3 I 8-3 I.

Hernández Pina, F. (1984). Teorias psicolingüisticas y su aplicación a la adquisición del español como lengua materna. Madrid: Siglo XXI.

Hickmann, M. (2003). Children's discourse: Person, place and time across languages. Cambridge: Cambridge University Press.

Hirsh-Pasek, K. \& Golinkoff, R. M. (2006). Action meets the word: How children learn verbs. Oxford/New York: Oxford University Press.

Jackson-Maldonado, D. \& Maldonado, R. (200I). Determinaciones semánticas de la flexión verbal en la adquisición temprana del español. In C. Rojas Nieto \& L. de León Pasquel (eds), La adquisición de la lengua materna: español, lenguas mayas, eusquera, 165-200. México, DF: Universidad Nacional Autónoma de México.

Johnson, C. M. (I996). Desarrollo morfosemántico del verbo español: Marcaje de tiempo y aspecto en México y Madrid. In M. Pérez Pereira (ed.), Estudios sobre la adquisición del 


\section{U C CELL I}

castellano, catalán, eusquera y gallego: Actas del I Encuentro Internacional sobre Adquisición de las Lenguas, I47-55. Santiago de Compostela: Universidad de Santiago de Compostela.

Labov, W. \& Waletzky, C. (I967). Narrative analysis: Oral versions of personal experience. In J. Helm (ed.), Essays on the verbal and visual arts, I 2-44. Washington, DC: American Ethnological Society.

López Ornat, S., Fernández, A., Gallo, P. \& Mariscal, S. (r 994). La adquisición de la lengua española. Madrid: Siglo XXI.

MacWhinney, B. (2000). The CHILDES Project: Computational tools for analyzing talk. Hillsdale, NJ: Lawrence Erlbaum.

Morales, A. (I989). Manifestaciones de pasado en niños puertorriqueños de 2-6 años. Revista de Lingüística Teórica y Aplicada 27, I I 5-3 I.

Moreno de Alba, J. C. (I993). El español de América. México: Fondo de Cultura Económica.

Nelson, K. (1989). Monologue as the linguistic construction of self in time. In K. Nelson (ed.), Narratives from the crib, 284-308. Cambridge, MA: Harvard University Press.

Nelson, K. (1996). Language in cognitive development: Emergence of the mediated mind. New York, NY: Cambridge University Press.

Ninio, A. \& Snow, C. E. (1996). Pragmatic development. Boulder, CL: Westview Press.

Peronard, M. (1987). El lenguaje, un enigma. Valparaíso, Chile: Editorial Don Quixote.

Peterson, C. \& McCabe, A. (1983). Developmental psycholinguistics: Three ways of looking at a child's narrative. New York, NY: Plenum Press.

Piaget, J. (r 969). The child's conception of time. London: Routledge \& Kegan Paul.

Sachs, J. (1983). Talking about the there and then: The emergence of displaced reference in parent-child discourse. In K. E. Nelson (ed.), Children's language, I-28. Hillsdale, NJ : Lawrence Erlbaum.

Sebastián, E. \& Slobin, D. (r 994). Development of linguistic forms: Spanish. In R. Berman \& D. Slobin (eds), Relating events in narrative: A crosslinguistic developmental study, 239-84. Hillsdale, NJ : Lawrence Erlbaum.

Shirai, Y. \& Miyata, S. (2006). Does past tense marking indicate the acquisition of the concept of temporal displacement in children's cognitive development? First Language 26( I ), 45-66.

Silva-Corvalán, C. (2004). Sociolingüistica y pragmática del español. Washington, DC: Georgetown University Press.

Smith, C. (1980). The acquisition of time talk: Relations between child and adult grammars. Fournal of Child Language $7(2), 263-78$.

Uccelli, P. (2003). Time and narratives: The development of temporality in young Spanishspeaking children. Unpublished doctoral dissertation, Harvard Graduate School of Education.

Weist, R. \& Buczowska, E. (1987). The emergence of temporal adverbs in child Polish. First Language 7, 2 I 7-29. 
APPENDIX : Narrative components: coding manual (adapted from Hemphill, Uccelli, Winner, Chang \& Bellinger, 2002) Children's narrative utterances were broken down into clauses. A clause is defined as 'a unit that contains a unified predicate, ... [i.e.] a predicate that expresses a single situation (activity, event, state). Predicates include finite and nonfinite verbs, as well as predicate adjectives' (Berman \& Slobin, I 994: 660). Each narrative clause should be coded using only one narrative structure coding (\%nas).

\section{Narrative structure (\%nas)}

\$SETT Setting. Clauses that provide descriptive information about the spatio-temporal context of the events, the characters and any additional background information that provides the context of the narrated events. Clauses that refer to temporal setting were identified:

:TEM Temporal setting. Clauses that offer a temporal framework either for the entire narrative or for a specific fragment of it, e.g. Era verano 'It was summer time'; Eran las 5:30 de la tarde 'It was five thirty in the evening'; Cuando tenia tres años 'When I was three'.

\$EVNT Events. Clauses that report actions will be coded as events. Events constitute the backbone of the narrative as they are the components which advance the narrative plot.

:NV Non-verbal. This code is added when the event is reported non-verbally, via gestures or enactment. Events should be coded as $\mathrm{NV}$ when they are conveyed via non-verbal means EXCLUSIVELY.

:ONO Onomatopoeic. This code is added when the event is reported via onomatopoeic sounds WITHOUT BEING REPORTED VERBALLY. If the onomatopoeic forms refer to an event which is conveyed verbally conveyed, then the onomatopoeia should be coded as \$EVAL.

\$EVAL Evaluation. Clauses that provide affective or evaluative commentary on the events will be coded as evaluation. These clauses included onomatopoeic forms, intensifiers, adjectives, internal states and causality.

\$OPE Narrative opening, e.g. Habia una vez, Once upon a time; Te acuerdas cuando ..., Remember when ...

$\$ C L O S \quad N a r r a t i v e$ closing. Clauses that contain explicit expressions of termination, e.g. y colorín colorado este cuento se ha acabado, The end. 
\$NNAR Non-narrative talk. Clauses that are not part of the narrative. 'Yes' and 'no' answers to adult's questions, attention getters, child's questions and off-topic clauses irrelevant to the narrative.

\$UNC Unclassifiable.

ADDITIONAL CODES FOR REPETITION

\begin{tabular}{lll}
\hline & Interactional codes & \multicolumn{1}{c}{$\%$ nas } \\
\hline REP & Repetition & $\begin{array}{l}\text { Child's repetition of the information conveyed by her } \\
\text { interlocutor in the immediately preceding turn. } \\
\text { Child's repetition of child's own information conveyed } \\
\text { in previous turns. }\end{array}$ \\
\hline
\end{tabular}

